\title{
Pola Penggunaan Lahan Berdasarkan Kelas Kemampuan Lahan di Sub- Sub DAS Kunisi Hulu DAS Jeneberang Kabupaten Gowa
}

\author{
Wahyuni ${ }^{1 *}$, Usman Arsyad ${ }^{1}$, Anwar Umar ${ }^{1}$, Reza Ashari Wirawan² \\ ${ }^{1}$ Staf Pengajar Fakultas Kehutanan, Universitas Hasanuddin, Makassar; \\ 2Praktisi Bidang Kehutanan \\ *Email: wahyuni@unhas.ac.id
}

\begin{abstract}
The research aims to determine the extent of land use suitability with land capability in Kunisi subs watershed of Jeneberang's upstream watershed. This research is expected to provide guidelines and consideration for related institution in conducting socialitation and enlightment in the field of soil conservation for farmers at Manimbahoi and Bilanrengi Village of Gowa regency. The method used in this study was image analysis by using software GIS and field observations conducted in Kunisi subs watershed of Jeneberang's upstream watershed. The research was carried from December 2014 to January 2015. The results showed that the uses of land in the subs watershed of Kunisi were for forest, gardens, rice fields, and shrubs with various level of land capability qualification IIIE, IIIb, IIIk, IVe, IVI, Vp, VII, and VIII. In the land unit found in the field there was mismatch land capability and land use. Such discrepancy can be resolved by restoring the function of land use based on its relevance and implement appropriate soil conservation techniques based on land capability classes.
\end{abstract}

Keywords: land use, land capability class, Kunisi subs watershed

\section{PENDAHULUAN}

Berdasarkan hasil analisis citra tahun 2008 oleh Dinas Kehutanan Provinsi Sulawesi Selatan dalam Millang (2010), luas lahan kritis di Sulawesi Selatan adalah 682.784 ha yang terdiri atas 369.965 ha didalam kawasan hutan dan 312.828 ha diluar kawasan hutan sedangkan laju rehabilitasi lahan kritis hanya 20.000 ha/tahun. Hal ini mengakibatkan penurunan kualitas Daerah aliran Sungai (DAS), dimana salah satu penyebabnya adalah kesalahan penggunaan lahan. Penggunaan lahan pertanian pada daerah-daerah yang terjal tanpa diiringi penerapan teknologi konservasi tanah dan air (Harjianto dkk., 2016).

Kesalahan penggunaan lahan ini menampakkan kecenderungan yang meningkat seiring laju pertumbuhan penduduk yang memberi tekanan terhadap sumberdaya alam hutan di daerah bagian hulu. Sedangkan luas lahannya tetap maka diperlukan perhatian yang serius dari berbagai pihak terhadap masalah penggunaan lahan. Penggunaan lahan haruslah memenuhi persyaratan yang diperlukan agar lahan tersebut dapat berproduksi serta tidak mengalami kerusakan untuk jangka waktu yang tidak terbatas (Sitorus, 1995 dalam Tarru, 2013).

Kesalahan penggunaan lahan mengakibatkan banyaknya terjadi kerusakan sehingga pemerintah dan masyarakat secara bersama-sama perlu melakukan upaya-upaya pencegahan. Upaya-upaya yang dilakukan ini dimaksudkan untuk mengatasi atau meminimalisir kerusakan yang mungkin terjadi sehingga produktifitas suatu lahan dapat dipertahankan atau bahkan dapat ditingkatkan.

Rahim (2006) menuturkan bahwa penggunaan lahan secara tepat guna dan berhasil guna hanya akan terjadi bila dilakukan berdasarkan kemampuan alami yang dimiliki oleh lahan itu, karena setiap lahan mempunyai kemampuan yang tidak sama. Dengan cara pengelolaan lahan yang tepat guna, produktifitas lahan dapat dipertahankan agar tercapainya produktifitas yang optimal dari suatu lahan dan tidak menimbulkan kerusakan. Salah satu upaya dalam pemanfaatan lahan (sumberdaya lahan) sesuai dengan potensinya dapat dilakukan berdasarkan evaluasi 
kemampuan lahan kemudian membuat klasifikasinya. Evaluasi ini sangat diperlukan sebagai penunjang dalam rangka penyusunan kebijakan, pemanfaatan lahan dan pengelolaan secara berkesinambungan (lestari).

Berbagai pola penggunaan lahan pada umumnya dapat ditemukan di seluruh wilayah sebab berhubungan dengan kegiatan manusia pada sebidang lahan. Bagian hulu merupakan daerah yang memiliki ketinggian lebih besar dibanding daerah sekitarnya dengan kemiringan lereng $>15 \%$ dan pada umumnya jenis vegetasinya merupakan hutan tegakan (Asdak, 2010). Bagian hulu DAS terdapat banyak percabangan sungai dimana percabangan dari sungai utama disebut Sub DAS sedangkan percabangan sungai pada Sub DAS disebut Sub-sub DAS.

Lokasi penelitian yang berada di Sub-sub DAS Kunisi merupakan hulu DAS Jeneberang. Secara administratif, Sub-sub DAS Kunisi berada di antara dua Kecamatan yaitu Kecamatan Parigi dan Kecamatan Tinggimoncong, Kabupaten Gowa, Sulawesi Selatan. Bagian hulu merupakan daerah yang memiliki ketinggian lebih besar dibanding daerah sekitarnya dengan kemiringan lereng $>15 \%$ dan pada umumnya jenis vegetasinya merupakan hutan tegakan (Asdak, 2010). Hulu DAS Jeneberang sudah mulai mengalami perubahan pemanfaatan lahan yang disebabkan oleh aktifitas masyarakat yang semakin banyak yang dapat memberikan pengaruh terhadap kualitas air di Sub DAS Kunisi. Berdasarkan uraian tersebut maka dilakukan penelitian mengenai "Pola Penggunaan Lahan Berdasarkan Kelas Kemampuan Lahan di Sub-sub DAS Kunisi, Hulu DAS Jeneberang".

\section{METODE PENELITIAN}

\subsection{Waktu dan Tempat}

Penelitian ini dilakukan pada Bulan Desember 2014 hingga Januari 2015 melalui dua tahapan, yaitu kegiatan lapangan di sub-sub DAS Kunisi, Hulu DAS Jeneberang, Kabupaten Gowa, dan kegiatan laboratorium dilakukan di Laboratorium IImu Tanah, Fakultas Pertanian, Universitas Hasanuddin.

\subsection{Prosedur Penelitian}

Peta penutupan lahan, peta geologi, peta topografi, peta curah hujan, peta jenis tanah, dan peta administrasi dioverlay untuk pembuatan peta unit lahan. Selanjutnya identifikasi pola penggunaan lahan aktual melalui analisis peta dan observasi lapangan. Data-data yang diperoleh langsung dari lapangan adalah pengukuran nilai kelerengan, erosi yang terjadi, kedalaman tanah, ancaman banjir, batuan dan drainase, pengambilan titik koordinat unit lahan aktual, pengambilan sampel tanah. Data kepekaan erosi, tekstur, permeabilitas dan salinitas diperoleh dari analisis laboratorium.

\subsection{Analisis Data}

Analisis data dilakukan melalui tahapan :

a. Pola penggunaan lahan diklasifikasikan berdasarkan kelas kemampuan lahan yang menggunakan metode matching (Arsyad, 2010) yaitu dengan cara pengelompokan kriteria-kriteria klasifikasi pada setiap unit lahan yang telah diperoleh melalui pengamatan di lapangan dan laboratorium.

b. Menyesuaikan kelas dan sub-kelas kemampuan lahan setiap unit lahan dengan pola penggunaan lahan yang telah diterapkan oleh masyarakat. 
c. Menentukan arahan penggunaan lahan pada unit lahan yang tidak sesuai antara kelas kemampuan lahannya dengan pola penggunaan lahannya.

\section{HASIL DAN PEMBAHASAN} pada Tabel 1.

Berdasarkan hasil overlay, maka diperoleh data unit lahan seperti yang disajikan Tabel 1. Unit Lahan Sub-sub DAS Kunisi

\begin{tabular}{cllcclc}
\hline $\begin{array}{c}\text { No. } \\
\text { Unit }\end{array}$ & Geologi & Jenis Tanah & $\begin{array}{c}\text { Kelas } \\
\text { Lereng (\%) }\end{array}$ & $\begin{array}{c}\text { Curah } \\
\text { Hujan } \\
(\mathrm{mm})\end{array}$ & $\begin{array}{c}\text { Penggunaan } \\
\text { Lahan }\end{array}$ & Luas (ha) \\
\hline 1 & $\begin{array}{l}\text { Batuan } \\
\text { Gunungapi }\end{array}$ & Dystrandept & $0-8$ & 304,58 & Sawah & 16,52 \\
\hline 2 & $\begin{array}{l}\text { Batuan } \\
\text { Gunungapi }\end{array}$ & Dystrandept & $8-15$ & 304,58 & Sawah & 66,66 \\
\hline 3 & $\begin{array}{l}\text { Batuan } \\
\text { Gunungapi }\end{array}$ & Dystrandept & $15-25$ & 304,58 & $\begin{array}{l}\text { Hutan } \\
\text { sekunder }\end{array}$ & 151,75 \\
\hline 4 & $\begin{array}{l}\text { Batuan } \\
\text { Gunungapi }\end{array}$ & Dystrandept & $25-40$ & 304,58 & $\begin{array}{l}\text { Hutan } \\
\text { sekunder }\end{array}$ & 306,97 \\
\hline 5 & $\begin{array}{l}\text { Batuan } \\
\text { Gunungapi }\end{array}$ & Dystrandept & $40-60$ & 304,58 & $\begin{array}{l}\text { Hutan } \\
\text { sekunder }\end{array}$ & 85,96 \\
\hline 6 & $\begin{array}{l}\text { Batuan } \\
\text { Gunungapi }\end{array}$ & Dystrandept & $>60$ & 304,58 & Sawah & 13,56 \\
\hline 7 & $\begin{array}{l}\text { Batuan } \\
\text { Gunungapi }\end{array}$ & Haplorthox & $0-8$ & 304,58 & Kebun & 82,01 \\
\hline 8 & $\begin{array}{l}\text { Batuan } \\
\text { Gunungapi }\end{array}$ & Haplorthox & $8-15$ & 304,58 & Sawah & 272,74 \\
\hline 9 & $\begin{array}{l}\text { Batuan } \\
\text { Gunungapi }\end{array}$ & Haplorthox & $15-25$ & 304,58 & Kebun & 84,20 \\
\hline 10 & $\begin{array}{l}\text { Batuan } \\
\text { Gunungapi }\end{array}$ & Haplorthox & $25-40$ & 304,58 & Kebun & 90,89 \\
\hline 11 & $\begin{array}{l}\text { Batuan } \\
\text { Gunungapi }\end{array}$ & Haplorthox & $40-60$ & 304,58 & Kebun & 93,76 \\
\hline 12 & $\begin{array}{l}\text { Batuan } \\
\text { Gunungapi }\end{array}$ & Haplorthox & $>60$ & 304,58 & $\begin{array}{l}\text { Hutan } \\
\text { sekunder }\end{array}$ & 60,65 \\
\hline 13 & $\begin{array}{l}\text { Batuan } \\
\text { Gunungapi }\end{array}$ & Tropudalfs & $8-15$ & 304,58 & Kebun & 14,07 \\
\hline 14 & $\begin{array}{l}\text { Batuan } \\
\text { Gunungapi }\end{array}$ & Tropudult & $0-8$ & 304,58 & $\begin{array}{l}\text { Semak } \\
\text { belukar }\end{array}$ & 16,92 \\
\hline 15 & $\begin{array}{l}\text { Batuan } \\
\text { Gunungapi }\end{array}$ & Tropudult & $8-15$ & 304,58 & Sawah & 32,38 \\
\hline 16 & $\begin{array}{l}\text { Batuan } \\
\text { Gunungapi }\end{array}$ & Tropudult & $15-25$ & 304,58 & $\begin{array}{l}\text { Semak } \\
\text { belukar }\end{array}$ & 61,01 \\
\hline 17 & $\begin{array}{l}\text { Batuan } \\
\text { Gunungapi }\end{array}$ & Tropudult & $25-40$ & 304,58 & Sawah & 65,86 \\
\hline 18 & $\begin{array}{l}\text { Batuan } \\
\text { Gunungapi }\end{array}$ & Tropudult & $40-60$ & 304,58 & Kebun & 25,41 \\
\hline 19 & Batuan & Tropudult & $>60$ & 304,58 & Kebun & \\
\hline & & & & & \\
\hline
\end{tabular}




\begin{tabular}{lcccrr}
\hline $\begin{array}{l}\text { No. } \\
\text { Unit }\end{array}$ & Geologi & Jenis Tanah & $\begin{array}{c}\text { Kelas } \\
\text { Lereng (\%) }\end{array}$ & $\begin{array}{c}\text { Curah } \\
\text { Hujan } \\
(\mathrm{mm})\end{array}$ & $\begin{array}{c}\text { Penggunaan } \\
\text { Lahan }\end{array}$ \\
\hline \multicolumn{7}{c}{ Luas (ha) } \\
\hline \multicolumn{7}{c}{ Total Luas } \\
\hline
\end{tabular}

\subsection{Kesesuaian Antara Penggunaan Lahan dengan Kelas Kemampuan Lahan}

Berdasarkan analisis kriteria kemampuan lahan di lapangan dan di laboratorium, diperoleh kelas kemampuan lahan/sub kelas dan kesesuaian penggunaan lahan yang dapat dilihat pada Tabel 2.

Tabel 2. Kesesuaian Penggunaan Lahan dengan Kelas Kemampuan Lahan

\begin{tabular}{|c|c|c|c|c|}
\hline $\begin{array}{l}\text { No. } \\
\text { Unit }\end{array}$ & $\begin{array}{l}\text { Penggunaan } \\
\text { Lahan Aktual }\end{array}$ & $\begin{array}{l}\text { Kelas } \\
\text { Kemampuan/sub } \\
\text { kelas }\end{array}$ & $\begin{array}{l}\text { Kesesuaian } \\
\text { Penggunaan } \\
\text { Lahan }\end{array}$ & Satuan Kemampuan/Pengelolaa \\
\hline 1 & Sawah & III/b & Sesuai & $\begin{array}{l}\text { Jika diusahakan untuk tanaman } \\
\text { semusim/pertanian, memerlukan } \\
\text { pengelolaan yang dapat } \\
\text { memelihara atau memperbaiki } \\
\text { struktur dan keadaan olah tanah } \\
\text { untuk mencegah pelumpuran dan } \\
\text { pemadatan dan memperbaiki } \\
\text { permeabilitas diperlukan } \\
\text { penambahan bahan organic serta } \\
\text { tidak mengolah tanah sewaktu } \\
\text { masih basah. }\end{array}$ \\
\hline 2 & Sawah & III/I & Sesuai & $\begin{array}{l}\text { Jika diusahakan untuk tanaman } \\
\text { semusim/pertanian, diperlukan } \\
\text { tindakan konservasi seperti } \\
\text { pembuatan teras, serta dapat } \\
\text { dikombinasikan dengan } \\
\text { penanaman strip rumput di bibir } \\
\text { teras sampai tampingan teras }\end{array}$ \\
\hline 3 & $\begin{array}{l}\text { Hutan } \\
\text { sekunder }\end{array}$ & $\mathrm{V} / \mathrm{p}$ & Sesuai & $\begin{array}{l}\text { Kelas lahan ini terbatas pilihan } \\
\text { penggunaan, tanaman dan } \\
\text { menghambat pengolahan tanah } \\
\text { bagi tanaman semusim. Perlu } \\
\text { pemeliharaan vegetasi penutup } \\
\text { tanah sebagai penahan erosi. }\end{array}$ \\
\hline 4 & $\begin{array}{l}\text { Hutan } \\
\text { sekunder }\end{array}$ & $\mathrm{VI} / /$ & Sesuai & $\begin{array}{l}\text { Jika digunakan untuk tanaman } \\
\text { semusim/pertanian, perlu } \\
\text { tindakan konservasi yang berat } \\
\text { seperti pembuatan teras bangku } \\
\text { yang baik, penerapan pola }\end{array}$ \\
\hline
\end{tabular}




\begin{tabular}{|c|c|c|c|c|}
\hline $\begin{array}{l}\text { No. } \\
\text { Unit }\end{array}$ & $\begin{array}{l}\text { Penggunaan } \\
\text { Lahan Aktual }\end{array}$ & $\begin{array}{l}\text { Kelas } \\
\text { Kemampuan/sub } \\
\text { kelas }\end{array}$ & $\begin{array}{l}\text { Kesesuaian } \\
\text { Penggunaan } \\
\text { Lahan }\end{array}$ & Satuan Kemampuan/Pengelolaa \\
\hline & & & & agroforestry multistrata \\
\hline 5 & $\begin{array}{l}\text { Hutan } \\
\text { sekunder }\end{array}$ & $\mathrm{VIII/I}$ & Sesuai & $\begin{array}{l}\text { Lahan kelas ini tidak sesuai } \\
\text { untuk budidaya pertanian. Jika } \\
\text { digunakan untuk padamg } \\
\text { rumput atau hutan produksi } \\
\text { harus dilakukan dengan usaha } \\
\text { pencegahan erosi yang berat }\end{array}$ \\
\hline 6 & Sawah & $\mathrm{V} / \mathrm{p}$ & Tidak sesuai & $\begin{array}{l}\text { Kelas lahan ini terbatas pilihan } \\
\text { penggunaan, tanaman dan } \\
\text { menghambat pengolahan tanah } \\
\text { bagi tanaman semusim. Hanya } \\
\text { sesuai untuk padang } \\
\text { pengembalaan, hutan produksi, } \\
\text { hutan lindung, dan cagar alam }\end{array}$ \\
\hline 7 & Kebun & III/e & Sesuai & $\begin{array}{l}\text { Jika diusahakan untuk tanaman } \\
\text { semusim/pertanian, diperlukan } \\
\text { tindakan konservasi seperti } \\
\text { penggunaan mulsa serta dapat } \\
\text { dikombinasikan dengan } \\
\text { penanaman strip dan pergiliran } \\
\text { tanaman. }\end{array}$ \\
\hline 8 & Sawah & $1 \mathrm{III/}$ & Sesuai & $\begin{array}{l}\text { Jika diusahakan untuk tanaman } \\
\text { semusim/pertanian, diperlukan } \\
\text { tindakan konservasi seperti } \\
\text { pembuatan teras, guludan } \\
\text { bersaluran, serta dapat } \\
\text { dikombinasikan dengan } \\
\text { penanaman strip rumput di bibir } \\
\text { teras sampai tampingan teras }\end{array}$ \\
\hline 9 & Kebun & IV/e & sesuai & $\begin{array}{l}\text { Untuk tanaman semusim } \\
\text { diperlukan pengelolaan dan } \\
\text { tindakan konservasi yang } \\
\text { intensif seperti perlakuan } \\
\text { kombinasi penggunaan mulsa, } \\
\text { pergiliran tanaman dengan } \\
\text { tanaman penutup tanah }\end{array}$ \\
\hline 10 & Kebun & IV/I & Sesuai & $\begin{array}{l}\text { Jika digunakan untuk tanaman } \\
\text { semusim diperlukan } \\
\text { pengelolaan dan tindakan } \\
\text { konservasi yang intensif seperti } \\
\text { perlukan kombinasi penggunan } \\
\text { mulsa, pergiliran tanaman }\end{array}$ \\
\hline
\end{tabular}




\begin{tabular}{|c|c|c|c|c|}
\hline $\begin{array}{l}\text { No. } \\
\text { Unit }\end{array}$ & $\begin{array}{l}\text { Penggunaan } \\
\text { Lahan Aktual }\end{array}$ & $\begin{array}{l}\text { Kelas } \\
\text { Kemampuan/sub } \\
\text { kelas }\end{array}$ & $\begin{array}{l}\text { Kesesuaian } \\
\text { Penggunaan } \\
\text { Lahan }\end{array}$ & Satuan Kemampuan/Pengelolaa \\
\hline & & & & dengan tanaman penutup tanah \\
\hline 11 & Kebun & $\mathrm{VII/I}$ & Tidak sesuai & $\begin{array}{l}\text { Jika digunakan untuk } \\
\text { tanamansemusim/pertanian, } \\
\text { perlu tindakan konservasi } \\
\text { seperti penerapan pola } \\
\text { agroforestry multistrata, lahan } \\
\text { ini lebih sesuai untuk padang } \\
\text { pengembalaan, hutan produksi, } \\
\text { hutan lindung atau cagar alam }\end{array}$ \\
\hline 12 & $\begin{array}{l}\text { Hutan } \\
\text { Sekunder }\end{array}$ & VIII/I & Sesuai & $\begin{array}{l}\text { Lahan kelas ini tidak sesuai } \\
\text { untuk budidaya pertanian. Jika } \\
\text { digunakan untuk padang rumput } \\
\text { atau hutan produksi harus } \\
\text { dilakukan usaha pencegahan } \\
\text { erosi yang berat disertai } \\
\text { tindakan pemupukan }\end{array}$ \\
\hline 13 & Kebun & $\mid \mathrm{III/}$ & Sesuai & $\begin{array}{l}\text { Jika diusahakan untuk tanaman } \\
\text { semusim/pertanian, diperlukan } \\
\text { tindakan konservasi seperti } \\
\text { pergiliran tanaman,pemberian } \\
\text { mulsa sebagai pencegah erosi }\end{array}$ \\
\hline 14 & Semak Belukar & $\| 11 / \mathrm{k}$ & Sesuai & $\begin{array}{l}\text { Jika diusahakan untuk tanaman } \\
\text { semusim/pertanian, } \\
\text { memerlukan pengelolaan yang } \\
\text { dapat memelihara atau } \\
\text { memperbaiki struktur tanah dan } \\
\text { keadaan olah tanah untuk } \\
\text { mencegah pelumpuran dan } \\
\text { pemadatan, memperbaiki } \\
\text { permeabilitas dan diperlukan } \\
\text { penambahan bahan organic } \\
\text { serta tidak mengolah tanah } \\
\text { sewaktu masih basah }\end{array}$ \\
\hline 15 & Sawah & $V / p$ & Tidak Sesuai & $\begin{array}{l}\text { Kelas lahan ini terbatas pilihan } \\
\text { penggunaan, tanaman dan } \\
\text { menghambat pengolahan tanah } \\
\text { bagi tanaman semusim. Hanya } \\
\text { sesuai untuk padang } \\
\text { penggembalaan, hutan } \\
\text { produksi, hutan lindung, dan } \\
\text { cagar alam }\end{array}$ \\
\hline
\end{tabular}




\begin{tabular}{|c|c|c|c|c|}
\hline $\begin{array}{l}\text { No. } \\
\text { Unit }\end{array}$ & $\begin{array}{l}\text { Penggunaan } \\
\text { Lahan Aktual }\end{array}$ & $\begin{array}{l}\text { Kelas } \\
\text { Kemampuan/sub } \\
\text { kelas }\end{array}$ & $\begin{array}{l}\text { Kesesuaian } \\
\text { Penggunaan } \\
\text { Lahan }\end{array}$ & Satuan Kemampuan/Pengelolaa \\
\hline 16 & Semak Belukar & IV/e & Sesuai & $\begin{array}{l}\text { Jika digunakan untuk tanaman } \\
\text { semusim diperlukan } \\
\text { pengelolaan dan tindakan } \\
\text { konservasi yang intensif seperti } \\
\text { penggunaan mulsa, pergiliran } \\
\text { tanaman, dan tanaman penutup } \\
\text { tanah }\end{array}$ \\
\hline 17 & Sawah & $111 / \mathrm{b}$ & Sesuai & $\begin{array}{l}\text { Jika diusahakan untuk tanaman } \\
\text { semusim/pertanian, } \\
\text { memerlukan pengelolaan yang } \\
\text { dapat memelihara atau } \\
\text { memperbaiki struktur tanah dan } \\
\text { keadaan olah tanah untuk } \\
\text { mencegah pelumpuran dan } \\
\text { pemadatan, memperbaiki } \\
\text { permeabilitas dan diperlukan } \\
\text { penambahan bahan rganic } \\
\text { serta tidak mengolah tanah } \\
\text { sewaktu masih basah }\end{array}$ \\
\hline 18 & Kebun & $\mathrm{VII/I}$ & Tidak sesuai & $\begin{array}{l}\text { Lahan kelas ini tidak sesuai } \\
\text { untuk budidaya pertanian. Untuk } \\
\text { penggunaan kebun atau hutan } \\
\text { produksi harus dilakukan usaha } \\
\text { pencegahan erosi yang berat } \\
\text { disertai tindakan pemupukan }\end{array}$ \\
\hline 19 & Kebun & VIII/ & Tidak sesuai & $\begin{array}{l}\text { Lahan kelas ini tidak sesuai } \\
\text { untuk budidaya pertanian. Jika } \\
\text { digunakan untuk padang rumput } \\
\text { atau hutan produksi harus } \\
\text { dilakukan usaha pencegahan } \\
\text { erosi yang berat disertai } \\
\text { tindakan pemupukan }\end{array}$ \\
\hline
\end{tabular}

Keterangan:

$b$ : faktor pembatas batuan

e : faktor pembatas erosi

I : faktor pembatas lereng

$p$ : faktor pembatas permeabilitas

k : faktor pembatas kedalaman tanah

Berdasarkan 19 unit lahan yang terbentuk terdapat lima bentuk penggunaan lahan yang tidak sesuai dengan satuan pengelolaan yang seharusnya, antara lain unit lahan $6,11,15,18$, dan 19. Di beberapa tempat terdapat unit lahan yang sesuai akan tetapi masih ditemukan penerapan teknik konservasi tanah yang kurang baik dan selebihnya sudah sesuai pada 
kemampuan lahannya. Untuk penggunaan yang tidak sesuai akan diberikan arahan dan yang sesuai cukup memelihara vegetasi penutup tanah serta memberi tindakan konservasi tanah dan air berdasarkan peruntukannya untuk memelihara daya dukung lahan.

Adapun persentase luasan areal penggunaan lahan yang sesuai dan tidak sesuai dapat dilihat pada Gambar 2.

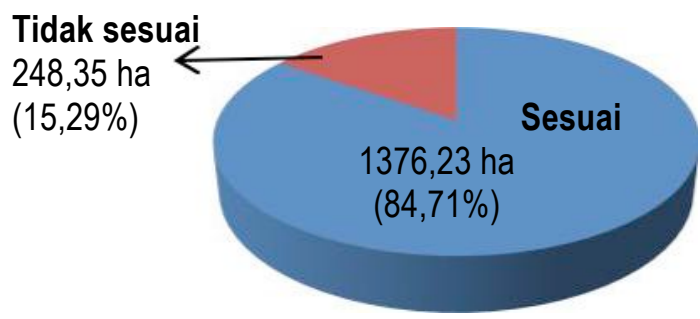

\section{Gambar 2. Persentase Kesesuaian Penggunaan Lahan}

\subsection{Arahan Penggunaan Lahan yang Sesuai dengan Penggunaannya}

Pada unit lahan 11 merupakan penggunaan lahan berupa kebun yang diklasifikasikan kedalam kelas kemampuan VI. Rahim (2000) mengemukaan pada unit lahan ini selain curam juga memiliki bahaya erosi sangat tinggi sehingga hampir tidak mungkin untuk tanaman semusim, begitu pula Arsyad (2010) berpendapat bahwa lahan kelas ini tidak sesuai digarap bagi usaha tanaman semusim tetapi lebih sesuai untuk tanaman rumput/pakan ternak atau vegetasi alami dengan pengelolaan yang baik. Unit lahan ini dapat menerapkan pola agroforestry multistrata dengan menggunakan tanaman yang telah dibudidayakan oleh masyarakat berupa kopi, alpukat, mangga, petai, nangka untuk meminimalisasi dampak ekologis seperti mengurangi laju erosi akibat aliran permukaan tanah serta memperbaiki struktur tanah oleh tanaman, juga bermanfaat dari segi ekonomi karena masyarakat dapat memperoleh hasil sepanjang tahun sehingga tidak tergantung kepada hasil panen satu jenis tanaman.

Unit lahan 18 dan 19 diklasifikasikan ke dalam kelas kemampuan VII dengan penggunaan lahan kebun dimana penggunaan lahan pada areal itu tidak sesuai untuk budidaya pertanian. Lahan kelas ini sebaiknya dipertahankan dengan vegetasi permanen. Untuk penggunaan perkebunan dan hutan produksi, harus melakukan tindakan pemupukan sebab pada lahan ini memiliki kendala yang memengaruhi tingkat kesuburan tanah disertai usaha konservasi tanah berupa agroforestry multistrata sebagai usaha pencegahan erosi. Sebaiknya kombinasi vegetasi agroforestry multistrata diusahakan bukan untuk lahan terbuka.

Menurut Suyana J. dan Muliawati E.S (2014), untuk lahan kelas VI yang daerah perakarannya dalam, tetapi terletak pada lereng yang curam jika digunakan untuk tanaman semusim (tegalan) harus dengan tindakan konservasi yang berat, seperti pembuatan teras bangku yang baik. Sedangkan untuk lahan kelas VII yang dalam keadaan tidak peka erosi jika digunakan untuk tanaman pertanian (tegalan) harus dibuat teras bangku yang baik disertai cara vegetative dan pemupukan.

Sedangkan unit lahan 6 dan 15 merupakan penggunaan lahan berupa sawah yang diklasifikasikan ke dalam kelas kemampuan $\mathrm{V}$, lahan kelas ini mempunyai hambatan yang tidak praktis dihilangkan serta membatasi pilihan macam penggunaan, tidak sesuai untuk ditanami dengan tanaman semusim, tetapi lebih sesuai untuk ditanami dengan vegetasi permanen atau dihutankan (Sitorus, 1985 dalam Manuputty dkk, 2014).

Beberapa unit lahan yang sesuai masih ditemukan penerapan teknik konservasi tanah yang kurang baik seperti pada unit lahan 7 dengan penggunaan berupa kebun yang diklasifikasikan ke dalam kelas kemampuan III yang memerlukan pengolahan tanah yang baik seperti penggunaan sisa-sisa tanaman baik berupa mulsa atau pupuk hijau. Sedangkan pada unit 
lahan 9 merupakan penggunaan lahan berupa kebun dengan kelas kemampuan IV yang memerlukan upaya-upaya konservasi tanah yang intensif dan harus selalu tertutup untuk memelihara kondisi fisik tanah disertai dengan penanaman dalam strip yang digunakan pada umumnya pada tanah yang diklasifikasikan menurut sistem klasifikasi kemampuan tanah diklasifikasikan ke dalam kelas II, III, dan IV. Pada unit lahan 9 memerlukan pengelolaan yang lebih hati-hati disebabkan pada areal ini tanahnya sangat labil sebab kerusakan erosinya agak berat.

\section{KESIMPULAN DAN SARAN}

\subsection{Kesimpulan}

Berdasarkan hasil penelitian yang diperoleh maka dapat ditarik kesimpulan bahwa:

a. Penggunaan lahan yang ada di sub-sub DAS Kunisi berupa hutan, sawah, kebun dan semak, dimana keempat bentuk penggunaan ini menghasilkan lima kelas kemampuan yaitu kelas III, IV, V, VI, dan VII dengan dominasi faktor penghambat adalah kelerengan.

b. Terdapat lima unit lahan yang tidak sesuai antara penggunaan lahan dengan daya dukung lahan seluas 248,35 ha $(15,29 \%)$, sedangkan total luasan yang sesuai sebesar 1376,23 ha $(84,71 \%)$. Meski demikian masih ditemukan penerapan teknik konservasi yang membutuhkan arahan.

c. Arahan penggunaan lahan yang tidak sesuai dengan daya dukung lahan di sub-sub DAS Kunisi dapat menggunakan teknik konservasi secara vegetatif, kimia, dan mekanik.

\subsection{Saran}

Sub-sub DAS Kunisi masih didominasi pohon-pohonan dengan penutupan hutan yang terjaga dengan cukup baik, oleh karena itu upaya pengelolaan sebaiknya memerhatikan kesesuaian penggunaan lahan disertai tindakan konservasi untuk meningkatkan nilai dan fungsi lahan, menjaga kondisi lahan dan kelestarian daerah aliran sungai.

\section{DAFTAR PUSTAKA}

Arsyad, S. 2010. Konservasi Tanah dan Air. Penerbit IPB Press, Bogor.

Asdak, C. 2010. Hidrologi dan Pengelolaan Daerah Aliran Sungai. Penerbit Gadjah Mada University Press, Yogyakarta.

Harjianto M., Sinukaban N., Tarigan S.D., Haridjaja O., 2016. Evaluasi Kemampuan Lahan untuk Arahan Penggunaan Lahan di Daerah Aliran Sungai Lawo, Sulawesi Selatan. Jurnal Penelitian Kehutanan Wallaceae Volume 5 Nomor 1 Hal. 1-11.

Manuputty, J., Gaspersz, E.Y. dan S.M. Talakua. 2014. Evaluasi Kemampuan Lahan dan Arahan Pemanfaatan Lahan Daerah Aliran Sungai Wai Tina Kabupaten Buru Selatan Provinsi Maluku. Agrologia, Jurnal IImu Budidaya Tanaman Volume 3.Tersedia online:http://evaluasi-kemampuan-lahan-agrologia:diakses pada September 2015.

Millang, S. 2010. Rehabilitasi Hutan dan Lahan Melalui Metode Air Seeding dan Ball Seeding di Sulawesi Selatan. Laboratorium Silvikultur, Fakultas Kehutanan Universitas Hasanuddin.

Rahim, S.E. 2006.Pengendalian Erosi Tanah Dalam Rangka Pelestarian Lingkungan Hidup. Penerbit Bumi Aksara, Jakarta. 
Sitohang J.L., Sitorus B., Sembiring M. 2013. Evaluasi Kemampuan Lahan Desa Sihiong, Sinar Sabungan dan Lumban Lobu Kabupaten Toba Samosir. Jurnal Online Agroekoteknologi Volume 1 Nomor 3 Hal. 842-852.

Suyana J. dan Muliawati E.S. 2014. Analisis Kemampuan Lahan pada Sistem Pertanian di Sub DAS Serang Daerah Tangkapan Waduk Kedung Ombo. Jurnal IImu Tanah dan Agroklimatologi 11 (2) Hal. 139-149.

Tarru,S. 2013.Penggunaan Lahan Pada Berbagai Kelas Kemampuan Lahan di Sub DAS Kelara Bagian Hulu Pada Desa Jenetallasa Kecamatan Rumbia Kabupaten Jeneponto.Jurnal Mahasiswa Pascasarjana.Tersedia online:http://kelas-kemampuan-lahan-das-kelara : diakses pada September 2015. 